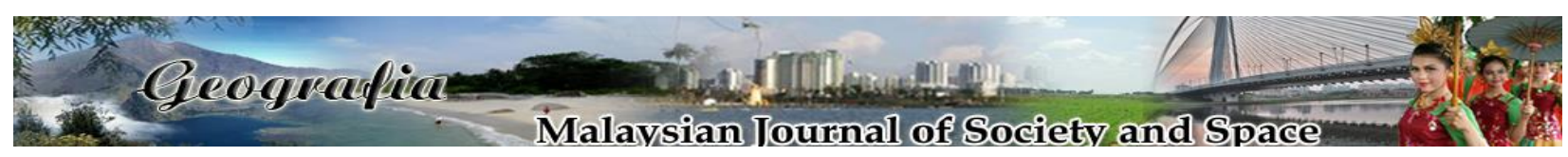

\title{
The spatial relation between land use and crime
}

\author{
Izatul Yusof, Rosmadi Fauzi \\ Department of Geography, Faculty of Arts and Social Sciences, University of Malaya \\ Correspondence: Izatul Yussof (email: izatulyussof@gmail.com)
}

Received: 27 January 2019; Accepted: 8 April 2019; Published: 14 May 2019

\begin{abstract}
Crime is often associated with social and economic problems. However, studies also showed that land use factor can cause crime. In Malaysia, zoning system is used to manage and administer land use in urban or rural areas. This study was, therefore conducted to measure the spatial distance and the strength of spatial distance between land use and crime. The analysis was done based on motorcycle thefts within a period of three years (2012-2014) in the Federal Territory of Putrajaya. The overlay map and multiple buffer zone techniques in the Geographic Information System (GIS) application were used to determine the spatial distance of land use. Chi Square statistical analysis and the Eta $(\eta)$ coefficient were used to see the strength of relationship between spatial distance of land use and crime. The results of the analysis showed that there was a significant and strong relationship between land use, spatial distance and motorcycle theft. The analysis indicated that the motorcycle theft incidences were concentrated on a very close distance at commercial, leisure and recreational areas, and residential areas at a distance of between $0 \mathrm{~m}$ and $150 \mathrm{~m}$. In the context of motorcycle thefts, residential and commercial land use have become the generators of motorcycle assets. This situation is also an indirect driving factor for motorcycle thefts. It therefore follows that spatial prevention and control should be given to land use that generates motorcycle assets.
\end{abstract}

Keywords: crime, land use, motorcycle theft, urban land use, urban spatial distance, zoning system

\section{Introduction}

In Malaysia, the zoning system was set up in the Local Plan (LP) and Structure Plan (SP) for an area, where each lot of land was gazetted for use according to the development plan. This zoning system is very important in land use planning and control pursuant to Section 2 of the Federal Territory Planning Act 1982 (Act 267) which includes land as:

a. Surface, and all substances forming the Earth's surface;

b. All substances below the Earth's surface; 
c. All vegetation and other natural products, whether or not requiring periodical application of labour to their production, and whether on or below the Earth's surface;

d. All things, whether on or below the Earth's surface, that are attached to the Earth or permanently fastened to anything attached to the Earth;

e. Land covered by water; and

f. Any estate or interest in, or right over, land.

Land was also classified and gazetted to a number of uses according to the zoning system, including residential, commercial, and industrial, public utilities, open space, agriculture and so on. The nature of activity was also closely related to this predetermined land use type. For example, business activities are carried out on commercial land use. Section 2 of the Federal Territory Planning Act 1982 (Act 267) defines each type of land use as:

a. Residential use: For human habitation of any land or building or part thereof including gardens, grounds, garages, stables, and out-houses, appertaining to such building;

b. Commercial use: Land or building or part thereof for purposes of commerce;

c. Industrial use: Includes the use of any land or building or part, thereof for purposes of industry;

d. Public place: Includes any place, building or road which is open to the use and enjoyment of the public or where the public have or are permitted to have access whether on payment or otherwise;

e. Open space: Any land whether enclosed or not which is laid out (or reserved for laying out) wholly or partly as a public garden, park, sport and recreation ground or pleasure ground or walk, or as a public place.

\section{Literature review}

Nowadays, new cities rise very fast especially in the suburbs. This situation is in line with the increased in population and demand for housing, public utilities and so on. There is nothing wrong with the existence of these new towns, however, several studies have linked land use with crime. Among these studies, land use factors have been linked to the differences in the number of crimes in one place (Kinney et al., 2008; Paulsen, 2012). In fact, studies have proved there was a relation between land use, urban form, routine and criminal activity (Suryavanshi, 2001). This relation shows that land use is important to form new cities. The result of a city design will affect daily activities, but a daily routine is an opportunity for a crime (Figure 1).

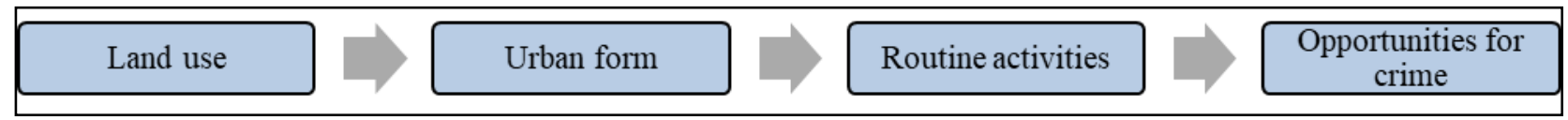

Sources: Suryavanshi, 2001.

Figure 1. Relationship between land use and criminal opportunities

Today's urban planning emphasises more on development by using the mixed development concept. Mixed development is a development that combines several types of land use in one development, for example, a mix of residential, commercial, public utilities, infrastructure and 
utilities. A development that uses this mixed development provides convenience to the people living around it. Several studies have shown that the use of these lands can prevent crime occurrence by reducing their distance. Studies by Jacobs (1961), Newman (1973), Browning et al. (2010), and Zahnow (2018) have found that mixed development was able to reduce crime rates. Another study by Anderson et al. (2013) found that commercial and residential mixed land use showed lower number of crimes as compared to commercial land use only. This was because mixed development yields high density land use. High density land use was also believed to influence criminal activities. Additionally, a study by Twinam (2017) found that high-density mixed development tended to be safer as high-density land use zones can enhance neighbourhood security by generating more road traffic, especially in commercial areas.

However, some studies showed a contradicting result of the mixed development findings. The study by Nor Eeda (2006) showed that mixed development can prevent crime occurrence. Wilcox et al. (2004) discovered that a commercial area that was adjacent to a residential area would increase the crime rate. A recent study by Wo (2019) found that the effects of mixed land use on neighborhood crime are relatively similar to other land use and sociodemographic effects. In fact, studies conducted by Schneider and Kitchen (2007) showed that residential areas that were mixed with playgrounds were also faced with the risk of raising crime rates. This mixed land use also indirectly generated many activities. However, there was a study which linked social activities and land use. This was because activity or social environment was closely related to the type of land use. For example, recreational, commercial and residential land produces various activities. However, according to Zohreh et al. (2016) the application of the socio-physical approach, "park use" behaviour was influenced by several environmental characteristics, including physical environment, social environment, and cultural environment. This means that not all types of recreational land use have various activities since they are influenced by the above factors.

Kinney et al. (2008) stated that land use with many activities can influence the crime rate in a particular area. Commercial land use was a potential for criminal activity and becomes a focus of crime. This was due to commercial land use which has a large number of public spaces and the largest number of unidentified people, so it was difficult to maintain informal social control (Kalantari et al., 2016; Adel et al., 2016). In fact, this study was also supported by Dong (2016) work which showed that neighbourhoods with more shopping centres suffer more homebreaking crimes. At present, studies on land use associated with crime are widespread. However, there is a paucity of research on land use and crime relation measurement and the measurement of land use spatial distance that focuses on crime. This paper therefore measures the concentration of crime according to land use space distance and measures the strength of land use and crime spatial distance.

\section{Urban space concepts}

Space plays a very important role in urban areas because it connects allplaces within the city. In geography, place and location are defined as locations that are positioned in space (i.e. where something is). Whereas, places refer to roads, angles, parks, neighbourhoods, cities, countries and so on. A place has material existence, either as a built environment or natural environment (Vilalta, 2013). This is further emphasised by Gregory (2003), who argued that a place is a particular part of a space that is occupied by organisms or has physical features. In urban studies, space is defined as all types of space among buildings within a city, and other places are 
considered as urban spaces (Krier, 1979). The definition given by Jiang (1998), and Jiang and Liu (2009) divides urban environment into two, namely closed spaces and open spaces. Closed spaces are space entities, such as buildings, plots, and street blocks, while open spaces are spaces among the enclosed space (Figure 2). The open space of a city forms a connecting section, allowing people to travel in urban areas. As such, urban space is greatly influenced by the physical and human activities.

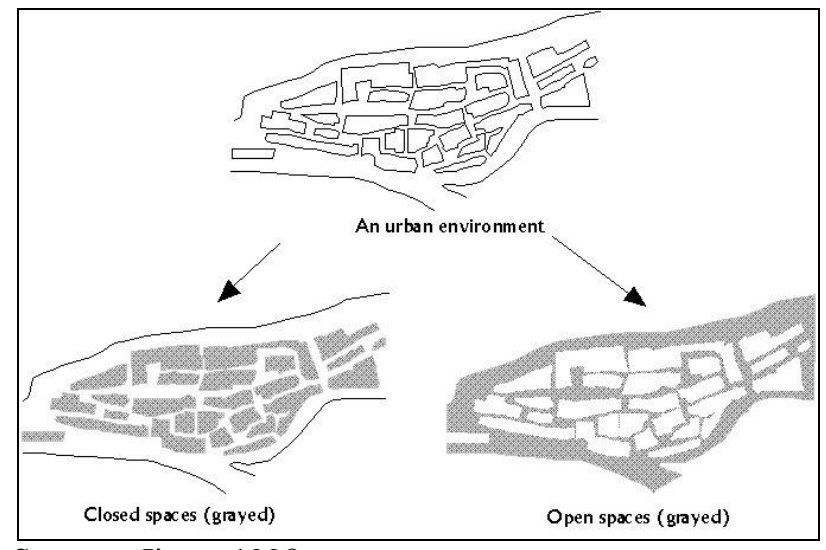

Sources: Jiang, 1998.

Figure 2. Closed space and open space

\section{Methods and study area}

The mixed method of combining quantitative and qualitative analyses were used in this study. Secondary data for the quantitative analysis were obtained from the Criminal Investigation Department at Bukit Aman Police Headquarters, Malaysia for three years from 2012 to 2014 in the form of excel spreadsheets. This study focused on motocycle thefts. Information, such as the address of the scene, boundary of the police station, location/scene, date and time of incident, were obtained. Meanwhile, data and information on land use such as precinct boundary, land use size and road layout in the form of shapefile ( $\mathrm{shp}$ ) were obtained from the Department of Information Technology, Putrajaya Corporation. The observation method for qualitative analysis was carried out after quantitative analysis is completed. Based on the findings, the study's observation was focused on spatial only. Several environmental features and areas that were addressed during the observation were identified by opportunities, adjacent land use, police control systems, legal enforcement restrictions, and design safety quality. Entry and exit routes for the areas were also noted. The primary data outcome was very important to further quantify the quantitative data analysis.

The area selected for this research was in the Federal Territory of Putrajaya. The Federal Territory of Putrajaya has a total area of 4,931 hectares. A total of 3,184.7 hectares $(65 \%)$ of land was developed. On the other hand, there are 1,746.29 hectares still developing (Putrajaya Structure Plan 2025). The town planning in Putrajaya has divided Putrajaya into 20 precincts, covering Core Island (covering Precints 1, 2, 3 and 4), while other precints in Putrajaya are peripherals (Figure 3). 


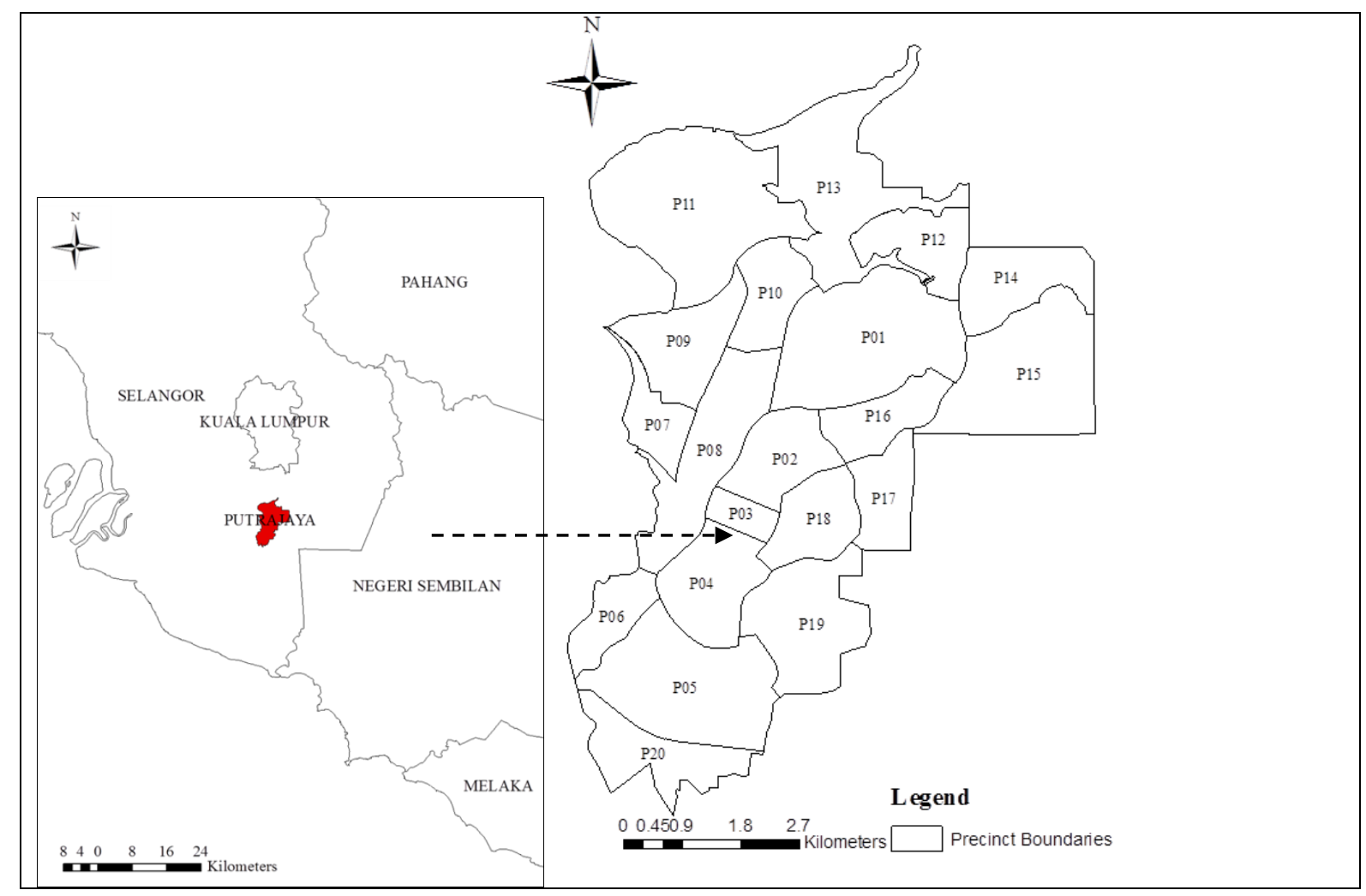

Figure 3. Map of Peninsular Malaysia and Map of Federal Territory of Putrajaya

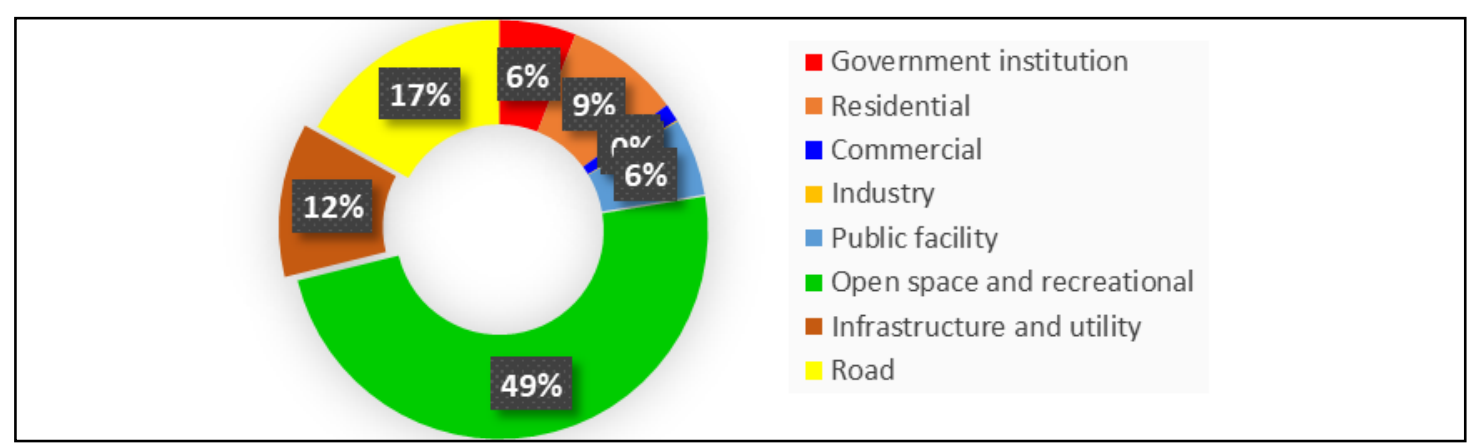

Sources: Perbadanan Putrajaya, n.d.

Figure 4. Land use in Putrajaya Federal Territory

The Federal Territory of Putrajaya is a new city and serves as the administrative centre for Malaysia. It has a more organised and comprehensive city planning scheme. The establishment of the Federal Territory of Putrajaya is intended to replace the Federal Territory of Kuala Lumpur (King, 2008). The land use in the Federal Territory of Putrajaya is divided into residential, commercial, industrial, governmental, leisure and recreational areas, infrastructure and utilities, public utilities and roads. Overall, the land use and recreation areas are the highest (49\%/1455.69 hectares) land use, followed by road (17\% /665.93 hectares), infrastructure and utilities (12\%/362.22 hectares) and land use for residential (9\%/281.06 hectares) (Putrajaya Structure Plan 2025) (Figure 4). The selection of this study area was based on completed data 
requirements and no changes in the land use status. This was because the study involved the period from 2012 to 2014 . The data can also help to analyse the process and directly generate research findings that can help Putrajaya in preventing motorcycle thefts.

\section{Develop Geographic Information System (GIS) database}

This research database was built by using Geographical Information System (GIS) application. GIS is a computerised database management system for storing, retrieving, analysing and displaying spatial data or information data defined by location (Worboys \& Duckham, 2004; Boba, 2005; Nasir, 2010; Chang, 2014). This study used the ArcMap software in ArcGIS Version 10.0 to develop the database.

The database design in this study was divided into spatial data and non-spatial data. Spatial data is the way GIS presents an object or location on the surface of the Earth (Nasir Nayan, 2010). Spatial data refers to the data displayed in the form of a map with titles, legends, scales and other elements in regard to geographic information for map readers. Meanwhile, non-spatial data refers to variables that describe spatial information. This data is stored inside ArcGIS by using ArcMap Version 10 through data entry and editing. Then non-spatial data is stored and presented in the form of tables or attributes. Generally, the process for developing a database in the GIS application for this study is shown in Figure 5;

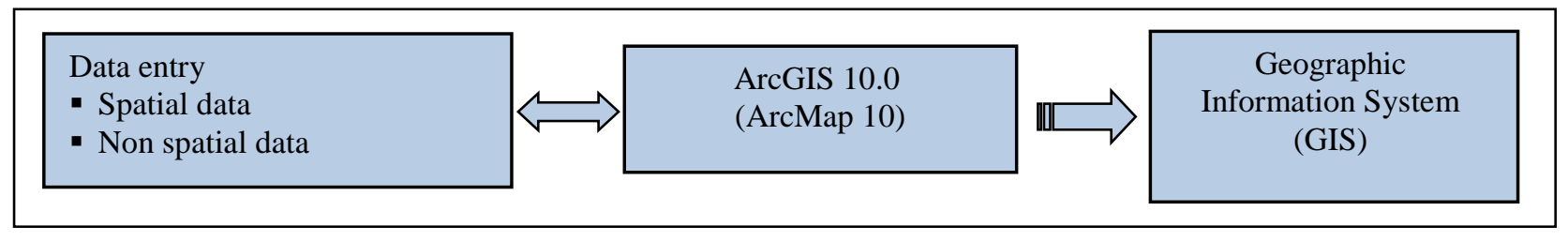

Figure 5. Database design in Geographic Information System

\section{Crime mapping}

Crime mapping needs to be done prior to analysis. Data for motorcycle thefts mapping was divided into two spatial and non-spatial data. Spatial data for motorcycle thefts was the data displayed above the map, which referred to the location/scene. This form of spatial data was represented by a point form and stored in shapefile (shp) format, whereas, non-spatial data was data, such as incident address information, location/event, date of occurrence, time and coordinates of X and Y. All non-spatial data were stored in the form of attributes or tables.

Map overlay techniques were used to produce crime mapping, i.e. overlay between crime points and polygons for land use. There are two layers of spatial data used to generate this motorcycle theft mapping. The first layer was spatial data on land use in the Federal Territory of Putrajaya. The second layer was a crime point. This overlay technique produces criminal mapping of the 2012's motorcycle thefts until 2014 (Figure 6). Meanwhile, selection by attribute technique was used to isolate motorcyle thefts against time. This study divided the time of crime into two, nighttime and daytime. 


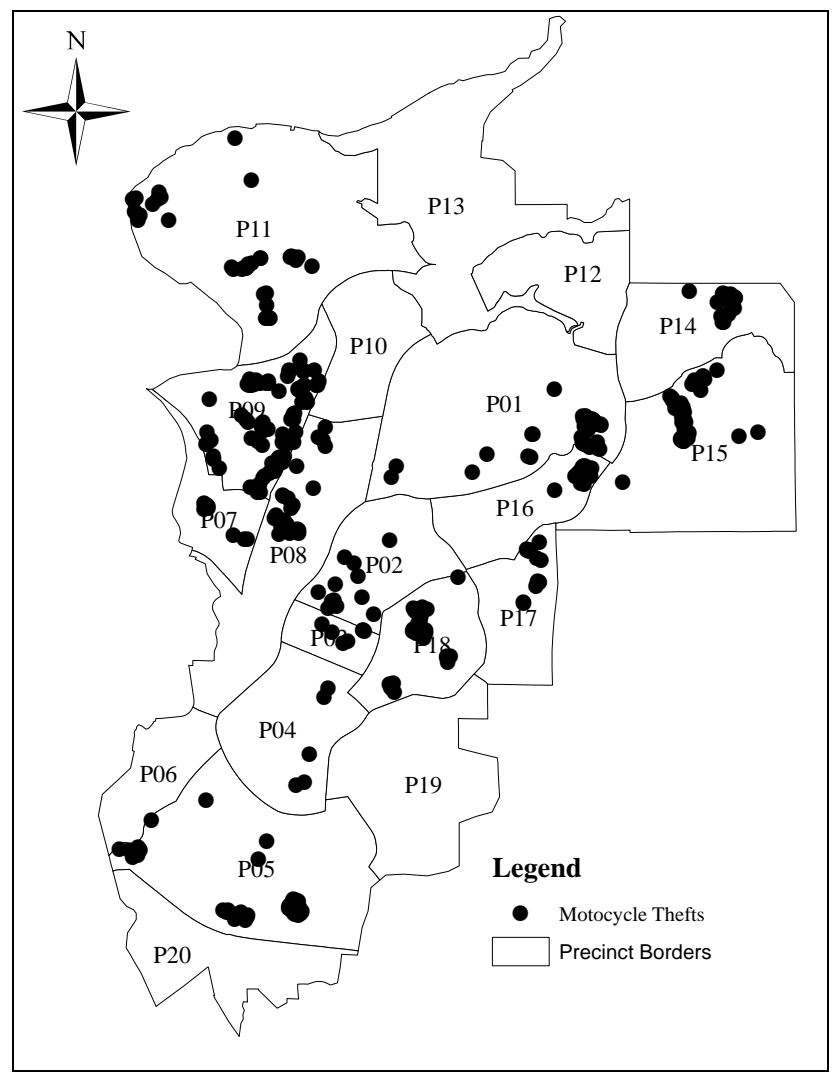

Figure 6. Mapping of motorcycle thefts in the Federal Territory of Putrajaya

\section{Data analysis technique}

\section{a. Multiple buffering}

The main data in this analysis was land use. The data form used in this analysis was data in the form of shapefile from the Department of Information Technology, Putrajaya Corporation. This study involved several types of land use. However, the use of infrastructure and utility land was not considered in this study. Utilisation of infrastructure and utilities represents 11 percent of total land use in Putrajaya, but it does not involve the use of a large space. An example is the drainage system, and so, there were only six types of land use analysed in this study, namely residential, commercial, services, community facilities, open space and government institutions. However, the use of land for commercial, industrial and public use has less land use than infrastructure and utilities, but the land has daily activities and greater land use polygons than infrastructure and utilities.

According to McCord and Ratcliffe (2009), there were no radius guidelines appropriate for use in land use and crime research. However, some previous researchers have used some radius in reviewing crime and land use (Table 1). Therefore, this study used a radius of $150 \mathrm{~m}$ to $1,350 \mathrm{~m}$, there were 10 radii, corresponding to the land use in Putrajaya (Figure 7). A total of 10 radii were used since it was found that no crime was recorded after a distance of 1,350 m. Zero value will affect relation analysis and to avoid this from happening the study hadto limit the radius to only 10 . 
Table 1. Summary of criminal analysis of crime and land use

\begin{tabular}{ccc}
\hline & Radius & Sources \\
\hline \multirow{2}{*}{ Land use } & 150 meters & Twinam (2015) \\
& 50 meters (Multiple Buffering) & Akpinar (2005) \\
& & Dutkowska \& Leitner (2017) \\
\hline
\end{tabular}

Multiple buffering techniques were used in this analysis. This technique began with the use of point-to-point measurements, measuring the distance between the point of crime and centroid land use. Centroid land use is derived from polygons. The calculate geometry method was used to obtain the coordinate of centroid $\mathrm{X}$ and centroid $\mathrm{Y}$ values for each lot of land use. Selection by location technique was used to obtain the number of crimes in each radius. The use of selected features in selection by location was used in choosing a radius, for example, a radius of $150 \mathrm{~m}$. The same technique was repeated for theft of motorcycles by time (day and night). As a result of this technique the number of crimes for each radius was obtained.

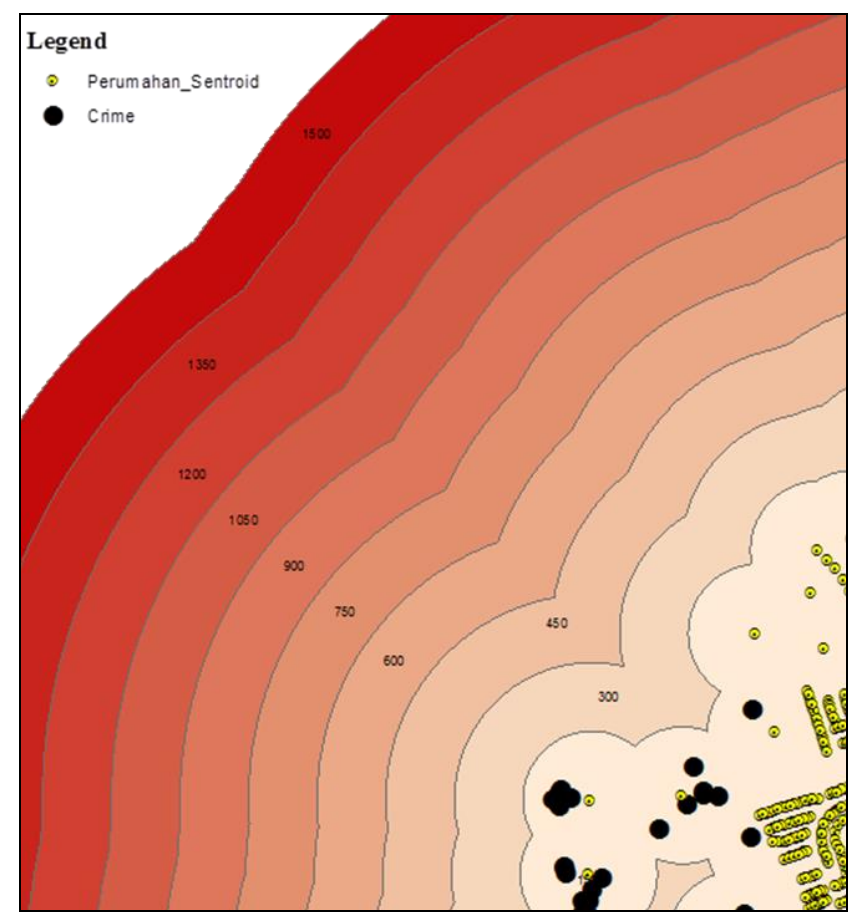

Figure 7. Multiple buffer zone for land use lot

b. Chi-square analysis technique

Chi-square test for independence was used in the analysis of relations between two variables in a nominal scale (data that can be categorised into separate groups) (Chua, 2006; Ghazali \& Sufean, 2016). This study used two variable categories, i.e. interval and nominal variables. However, the nominal data used were in the form of categories. Meanwhile, the interval variable in this study was the radius of the double buffer zone for distance (Table 2). 
Table 2. Spatial variable land use

\begin{tabular}{lll}
\hline & \multicolumn{1}{c}{ Interval variable } & Nominal variable (Category) \\
& & 1. Industry \\
& & 2. Government Institutions \\
Land use & Radius distance & 3. Public facility \\
& & 4. Commercials \\
& 5 to 150 meters (10 radius) & 6esidential \\
& & Open space and recreational \\
\hline
\end{tabular}

Chi-square test analysis was also used to see the strength of relationship between the two variables, i.e. by using the Eta $(\eta)$ coefficient value (Jacobsen, 2016). Eta $(\eta)$ coefficient value was used to measure relations between ratio variables or intervals and nominal variables. The value of the Eta $(\eta)$ coefficient is selected, when there are two variables, i.e. the interval and the nominal (category). Category variables must be encoded with numbers. In this study, category variables were the number of crimes in each land use lot by distance of spatial radius. Eta $(\eta)$ was measured starting from the zero-value, indicating no relation. Meanwhile, the value of Eta $(\eta)$ that approaches one shows a very strong relationship.

\section{Results and discussion}

The value of $\chi^{\wedge} 2(\mathrm{DK}=45, \mathrm{~N}=2190)=2628.27$ was the result of the Chi-Square test analysis between the spatial distance variable radius motorcycle thefts with the type of land use. The result of this analysis showed that there was a significant relationship at the one \% level between the variables. The resulting value $(\eta)=0.797$ indicated that there was a strong relation between the spatial distance radius of motorcycle theft and land use (Table 3). This showed that the spatial distance radius of land use was one of the factors that influenced motorcycle thefts in Putrajaya.

Based on the spatial distance radius, land use for the industry showed no motorcycle theft incident that occurred at a spatial distance radius between $0 \mathrm{~m}$ to $150 \mathrm{~m}$. However, crime began after the spatial distance radius between $150 \mathrm{~m}$ and above. This condition is due to industrial type i.e industrial in the service category and low density. There was a difference of spatial distance radius with a high number of motorcycle thefts for each type of land use. Land use for public facility and commercial showed the highest concentration of motorcycle thefts that occurred at spatial distance radius between $150 \mathrm{~m}$ to $300 \mathrm{~m}$, government institutions $(450 \mathrm{~m}$ to $600 \mathrm{~m})$. On the other hand, land use for residential and open space / recreation was at a spatial distance radius of between $0 \mathrm{~m}$ to $150 \mathrm{~m}$ (Table 4). This situation may be influenced by the generator factor or the number of motorcycles produced for the land use (Ibrahim, 1990). For example, the residential land use was a generator centre for motorcycles, with most motorcycles owned by residents.

The observation results found that there were several open spaces in Putrajaya, which were used as parking lots for cars and motorcycles, such as those found in Precinct 2 and Precinct 3. The open spaces were under surveillance and away from the public. Based on the theory by Newman (1996), natural surveillance is important as it involves designing a physical space in a way that allows people to observe the behaviour of friends and strangers. Jacobs (1961) suggested that "more eyes on the street" was an approach to reduce the chances of crime. Meanwhile, observations for residential land use found that high-density residential dwellers 
suffer from shortage of motorcycle parking spaces so much so that there were motorcycle owners who parked their motorcycles at the front porch and under trees. According to Newman (1996), and his theory of Defensible Space, the front of a building and bottom of a tree are included in the public space category that will invite many strangers. This causes security in this space to be quite difficult to manage.

Table 3. Statistic values and Eta $(\eta)$

\begin{tabular}{lccc}
\hline $\begin{array}{l}\text { Type of } \\
\text { crime }\end{array}$ & Overall & Day & Night \\
\hline $\begin{array}{l}\text { Motocycle } \\
\text { theft }\end{array}$ & $(\mathrm{Df}=45, \mathrm{~N}=2190)=2628.27$ & $\left(\mathrm{Df}=45, \begin{array}{l}\mathrm{N}=1047)=1133.77 \\
(\eta)=0.797\end{array}\right.$ & $\begin{array}{l}(\mathrm{Df}=45, \mathrm{~N}=1143)=1565.11 \\
(\eta)=0.833\end{array}$ \\
\hline
\end{tabular}

Note: $\quad$ (Degree of freedom, number of cases) $=\chi^{2}$ statistics. significant at one per cent level

Table 4. Cross table for spatial distance radius of land use and motorcycle thefts in the Federal Territory of Putrajaya

\begin{tabular}{lcccccc}
\hline \multirow{2}{*}{$\begin{array}{l}\text { Spatial distance } \\
\text { Radius, } \boldsymbol{D} \text { in } \\
\text { meters }\end{array}$} & $\begin{array}{c}\text { Industry } \\
(\boldsymbol{\%})\end{array}$ & $\begin{array}{c}\text { Public } \\
\text { facility (\%) }\end{array}$ & $\begin{array}{c}\text { Government } \\
\text { Institutions } \\
(\boldsymbol{\%})\end{array}$ & $\begin{array}{c}\text { Commercials } \\
(\boldsymbol{\%})\end{array}$ & $\begin{array}{c}\text { Open space } \\
\text { and } \\
\text { recreational } \\
(\boldsymbol{\%})\end{array}$ & $\begin{array}{c}\text { Residential } \\
(\boldsymbol{\%})\end{array}$ \\
\hline$D \leq 150$ & - & $62(15.0)$ & $27(7.0)$ & $136(33.0)$ & $346(85.0)$ & $317(78.0)$ \\
$150<D \leq 300$ & $2(1.0)$ & $229(56.0)$ & $35(9.0)$ & $147(36.0)$ & $61(15.0)$ & $28(7.0)$ \\
$300<D \leq 450$ & $15(10.0)$ & $72(18.0)$ & $84(21.0)$ & $85(21.0)$ & - & $43(11.0)$ \\
$450<D \leq 600$ & $9(6.0)$ & $28(7.0)$ & $120(29.0)$ & $36(9.0)$ & - & $13(3.0)$ \\
$600<D \leq 750$ & $24(15.0)$ & $15(4.0)$ & $75(18.0)$ & $3(1.0)$ & - & $4(1.0)$ \\
$750<D \leq 900$ & $16(10.0)$ & $1(0)$ & $36(9.0)$ & - & - & $2(1.0)$ \\
$900<D \leq 1050$ & $19(12.0)$ & - & $26(6.0)$ & - & - & - \\
$1050<D \leq 1200$ & $32(21.0)$ & - & $3(1.0)$ & - & - & - \\
$1200<D \leq 1350$ & $19(12.0)$ & - & $1(0)$ & - & - & - \\
$1350<D \leq 1500$ & $19(12.0)$ & - & - & - & - & - \\
\hline
\end{tabular}

The result of Chi-square analysis between spatial distance radius motorcycle thefts by time showed that the value of $\chi^{2}(\mathrm{DK}=45, \mathrm{~N}=1143)=1565.11$ was obtained at nighttime, and the value of $\chi^{2}(\mathrm{DK}=45, \mathrm{~N}=1047)=1133.77$ during the daytime. Both showed significant relations at the $1 \%$ level. It was found that the value of the Eta $(\eta)$ coefficient was higher at nighttime as compared to daytime, i.e. the value $(\eta)=0.833$ (nighttime) and the value $(\eta)=$ 0.764 (daytime). Both indicated that there was a strong relation with the spatial distance between motorcycle theft crimes and land use. Observation found that most high-density housing makes the rear of buildings as parkings for motorcycles. This allows the shadow of building to act as one of the factors that protect the occurrence of motorcycle thefts during night and day (Newman \& Frank, 1982; Newman, 1996; Ratti, 2004; Townsley et al., 2013). Other factors that help motorcycle thefts are nighttime darkness and loneliness (Atkins et al., 1991; Boomsma \& Steg, 2014). 


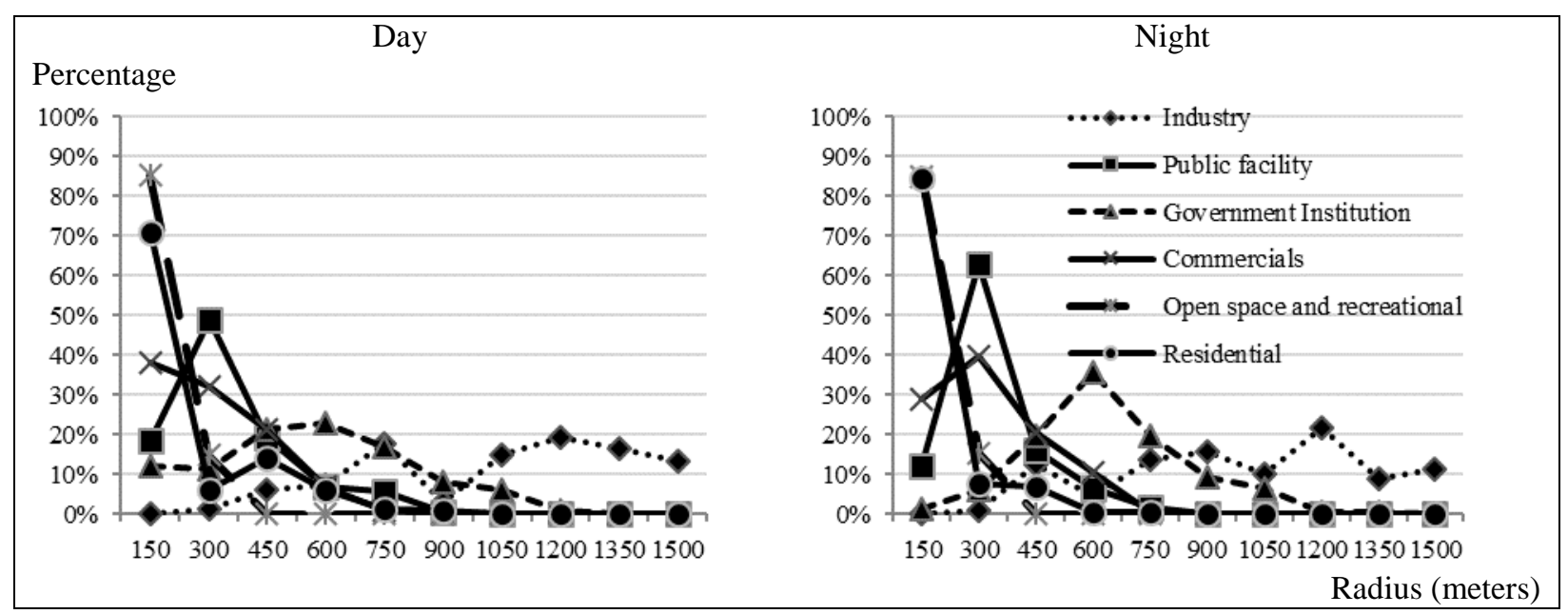

Figure 8. The graph for spatial distance radius of land use and motorcycle thefts by time of occurrence in the Federal Territory of Putrajaya

A comparison between motorcycle thefts at nighttime and daytime showed that there was a distinction between spatial distance radius by land use type. Commercial land use showed that there was a difference of motorcycle theft focused for spatial distance radius at nighttime and daytime spatial distance radius between $0 \mathrm{~m}$ and $150 \mathrm{~m}$ for motorcycle thefts during the daytime, while spatial distance radius between $150 \mathrm{~m}$ to $300 \mathrm{~m}$ for motorcycle thefts at nighttime. The observations result found that most motorcycles were not parked at premises that were provided in commercial areas, for example, an indoor parking space that is provided by shopping malls. Most motorcycle owners park their motorcycles at the pedestrian front of a commercial building. This condition provides an opportunity for motorcycle thefts due to lack of supervision. Even this space is sheltered behind the trees. On the contrary, land use for industries, public facilities, government institutions, open space and recreation as well as residential areas showed the same concentrations for spatial distance for motorcycle thefts at nightime and daytime. It can be summarised that spatial distance radius for industrial land use $(1050 \mathrm{~m}$ to $1200 \mathrm{~m})$, public facilities $(150 \mathrm{~m}$ to $300 \mathrm{~m})$, government institutions $(450 \mathrm{~m}$ to $600 \mathrm{~m})$, open space and recreations (0m to $150 \mathrm{~m})$ (Figure 8$)$.

The difference in the total of motorcycle thefts during the nighttime and daytime for land use of government institutions was influenced by the daily routine of the people who work as civil servants. This situation generates a high number of motorcycles in government land use. The motorcycles are not just owned by civil servants, but they are also public properties that come in contact with government departments. However, at night the motorcycle thefts decreased because the civil servants have returned home (Cohen \& Felson, 1979). This situation is in contrast to the situation at government institution buildings where there are many motorcycles near government institutions during daytime but decreases at nighttime. On the other hand, these motorcycles are nearer to residential areas at nighttime; thus, increases the number of motorcycles in residential land use. The space has become the focus of criminals since it is a less protected space, covered, and dark (at night) (Newman \& Frank, 1982; Newman, 1996; Ratti, 2004; Townsley et al., 2013).

Theoretically, it is necessary to integrate commercial land use with residences to increase street activities and impact on increased natural surveillance (Jacobs, 1961). The main purpose of 
this mixed land use is to increase the number of movements and indirectly increase the level of public surveillance through the 'eyes on the street' approach (Jacobs, 1961). In fact, previous studies conducted by Jacobs (1961); Newman (1973); Browning et al. (2010) had also pointed out that mixed land use was capable of reducing crime rates. In fact, the implementation of this mixed land use zone facilitates the residents as the facilities provided are located near residential areas that can save time and transport costs. Nevertheless, not all mixed land use can help to prevent crime. The findings showed that retail outlets, restaurants and offices have a positive role in improving security in residential areas. These findings showed that mixed land use between commercial and residential land is dependent on commercial types, and not all commercial land use increases crime (Dong, 2016). The study found that increased mobility was particularly appropriate for crimes, involving large assets, such as motorcycles, cars, homes and buildings. The results of the analysis also found that high human mobility can prevent motorcycle thefts by acting as natural observers.

\section{Conclusion}

The findings showed that spatial differentiation in land use has become one of the factors that contribute to motorcycle thefts in the Federal Territory of Putrajaya. In fact, this study proved that the spatial relation between land use and motorcycle theft crimes existed through metric measurements. Therefore, the outcome of this study was mainly focused on spatial motorcycle theft and can help the police, local authorities, PLANMalaysia, as well as relevant agencies, such as the Malaysian Crime Prevention Foundation (MCPF), including the private sector to work together, to set high targets for crime reduction. Prevention and control measures can be made on spatial focus on motorcycle thefts by land use type. Consideration should also be given to land use that generates motorcycle assets to ensure that adequate parking spaces areprovided and be placed in publicly accessible areas. This condition can be primarily controlled before obtaining a Planning Permission (PP) approval under Section 19 (1) of the Town and Country Planning Act 1976 (Act 172) and application for layout plans approval under the Road, Drainage, and Building Act 1974 (Act 133). This studyalso contributes in developing a theoretical framework that can be applied for future research, especially that relates to spatial factors for land use and crime.

The data and study scope need to be expanded and further refined for future research as there are several aspects to be considered. Firstly, it is necessary to obtain the completed building data for each land lot in accordance to the study duration. This is to ensure that the analysis is based on the actual situation that involves human activities. Secondly, more detailed studies can also be done by considering the types of building, such as schools, hotels, retail outlets, shopping malls and others (Dutkowska \& Leitner, 2017). Meanwhile, the residence can also be further detailed by residential types, such as detached houses, condominiums, semi-detached houses, terraces, flats, and apartments. Hourly surveys can also be conducted to see the relation between land use and crime against time (Matijosaitiene et al., 2018). Thesestudies would be more significant and interesting with more detailed analyses. 


\section{References}

Adel, H., Salheen, M., \& Mahmoud, R.A. (2016). Crime in relation to urban design. Case study: The greater Cairo Region. Ain Shams Engineering Journal, 7(3), 925-938. http://dx.doi.org/10.1016/j.asej.2015.08.009

Akpinar, E. (2005). Using Geographic Information Systems in analysing the pattern of crime incidents and the relationship between landuse and incidents (Master dissertation). Retrieved from The Graduate School of Natural and Applied Sciences, Middle East Technical University.

Anderson, J.M., MacDonald, J.M., Bluthenthal, R., \& Ashwood J.S. (2013). Reducing crime by shaping the built environment with zoning: An empirical study of Los Angeles. University of Pennsylvania Law Review, 161, 699-861.

Atkins, S., Hussain, S., \& Storey, A. (1991). The influence of street lighting on crime and fear of crime. Goverment Report, Office Crime Prevention Unit, London. Retrieved from http://www.celfosc.org.

Boba, R. (Ed.). (2005). Crime analysis and crime mapping. ( $3^{\text {rd }} \mathrm{ed}$.). London, New York, SAGE

Boomsma, C., \& Steg, L. (2014). The effect of information and values on acceptability of reduced street lighting. Journal of Environmental Psychology, 39, 22-31. http://dx.doi.org/10.1016/j.jenvp.2013.11.004

Browning, C.R., Byron, R.A., Calder, C.A., Krivo, L.J., Kwan, M.P., \& Lee, J.Y. (2010). Commercial density, residential concentration, and crime: Land use patterns and violence in neighborhood context. Journal of Research in Crime \& Delinquency, 47(3), 329-357. http://dx.doi.org/10.1177/0022427810365906

Chang, K.T. (Ed.). (2014). Introduction to Geographic Information Systems. ( $7^{\text {th }}$ ed.). Singapore, McGraw-Hill.

Chua, Y.P. (2006). Asas Statistik Penyelidikan. Kuala Lumpur, Malaysia, Mc Graw Hill.

Cohen, L.E., \& Felson, M. (1979). Social change and crime rate trends: A routine activity approach. American Sociological Review, 44(4), 588-608. http://dx.doi.org/10.2307/2094589

Dong, W.S. (2016). Do all commercial land uses deteriorate neighborhood safety? Examining the relationship between commercial land-use mix and residential burglary. Habitat International, 55, 148-158. http://dx.doi.org/10.1016/j.habitatint.2016.03.007

Dutkowska, N.S., \& Leitner, M. (2017). Land use influencing the spatial distribution of urban crime: A case study of Szczecin, Poland. ISPRS International Journal of Geo-Information, 6(74), 1-23. http://dx.doi.org/10.3390/ijgi6030074

Ghazali Darussalam \& Sufean Husssin (Eds.). (2016). Metodologi penyelidikan dalam pendidikan: Amalan dan analisis kajian. Kuala Lumpur, Penerbit Universiti Malaya.

Gregory, K. (2003). Place: The management of sustainable physical environments. In Holloway, Rice, S.P., \& Valentine, G. (Eds.), Key concepts in Geography (pp. 187-208). London, SAGE Publications.

Ibrahim Wahab. (Ed.). (1990). Teknik sistem lalu lintas dan pengangkutan. Kuala Lumpur, Dewan Bahasa dan Pustaka.

Jacobs, J. (Ed.). (1961). The death and life of American Cities. New York, Random House.

Jacobsen, K.H. (Ed.). (2016). Introduction to health research methods: A practical guide. (2 $2^{\text {nd }}$ ed.). Sudbury, Mass, Jones \& Bartlett Learning. 
Jiang, B. (1998). A space syntax approach to spatial cognition in urban environments: Cognitive Models of Dynamic Phenomena and their representations. Pittsburgh, University of Pittsburgh, Pittsburgh. Retrieved from http://www.pitt.edu

Jiang, B., \& Liu, C. (2009). Street- based topological representations and analyses for predicting traffic flow in GIS. International Journal of Geographical Information Science, 23(9), 1119-1137. http://dx.doi.org/10.1080/13658810701690448

Kalantari, M., Ghavagh, A.R., Toomanian, A., \& Dero, Q.Y. (2016). A new methodological framework for crime spatial analysis using Local Entropy Map. Modern Applied Science, 10(9), 179-190. http://dx.doi.org.10.5539/mas.v10n9p179

King, R. (Ed). (2008). Kuala Lumpur and Putrajaya: negotiating urban space in Malaysia. Singapore, Asian Studies Association of Australia in association with NUS and NIAS Press.

Kinney, J.B., Brantingham, P.L., Wuschke, K., Kirk, M.G., \& Brantingham, P.J. (2008). Crime attractors, generators and detractors: Land use and urban crime opportunities. Built Environment, 34(1), 62-74.

Krier, R. (Ed.) (1979). Urban space. United Kingdom, Rizzoli International Publications.

Malaysia. (1996). Akta Perancangan Wilayah Persekutuan 1982 (Akta 267).

Matijosaitiene, I., Zhao, P., Jaume, S., \& Gilkey Jr, J.W. (2018). Prediction of hourly effect of land use on crime. ISPRS Int. J. Geo-Inf, 8(1), 16. http://dx.doi.org.10.3390/ijgi8010016

McCord, E.S., \& Ratcliffe, J.H. (2009). Intensity value analysis and the criminogenic effects of land use features on local crime patterns. Crime Patterns and Analysis, 2(1), 17-30.

Nasir Nayan. (Ed.). (2010). Manual ArcGIS: Amali AcMap dan ArcCatalog. Perak, Penerbit Universiti Pendidikan Sultan Idris, Tanjong Malim.

Newman, O. (Ed.). (1973). Architectural design for crime prevention. Washington, D.C., Law Enforcement Assistance Administration, National Institute of Law Enforcement and Criminal Justice. Retrieved from https://www.ncjrs.gov

Newman, O., \& Frank, K.A. (1982). The effect of building size on personal crime and fear of crime. Urban Residential Environment Part II, 5(4), 203-220.

Nor Eeda Ali. (2006). Pembangunan Komuniti dalam Pelaksanaan Konsep Bandar Selamat. Universiti Teknologi Malaysia, Fakulti Alam Bina, Johor (Master dissertation). Retrieved from http://eprints.utm.my.

Paulsen, D.J. (Ed.). (2012). Crime and planning: Building socially sustainable communities. New York, CRC Press, Taylor \& Francis Group.

Perbadanan Putrajaya (n.d.). Laporan Pemeriksaan. Draf Rancangan Struktur Putrajaya. Wilayah Persekutuan Putrajaya, Malaysia.

Ratti, C. (2004). Urban texture and space syntax: some inconsistencies. Environment and Planning B: Planning and Design, 31, 1-12. http://dx.doi.org.10.1068/b3019

Schneider, R.H., \& Kitchen, T. (Eds). (2007). Crime prevention and the built environment. London, New York, Routledge.

Suryavanshi, V.M. (2001). Land use and opportunities for crime: Using GIS as an analysis tool (Master dissertation). Retrieved from Faculty of the Virginia Polytechnic Institute and State University, Blacksburg, Virginia.

Townsley, M., Reid, S., Rynne, J., \& Hutchins, B. (2013). Crime in high rise buildings: Planning for vertical community safety. Criminology Research Grants, Criminology Research Advisory Council. Retrieved from http://www.criminologyresearchcouncil.gov.au 
Twinam, T. (2015). Danger zone: Local government land use regulation and neighborhood $\begin{array}{lllll}\text { crime. Journal of Urban } & \text { Economics } & 100,111 .\end{array}$ http://dx.doi.org/10.1016/j.jue.2017.05.006

Twinam, T. (2017). Danger zone: Land use and the geography of neighborhood crime. Journal of Urban Economics, 100, 104-119. http://dx.doi.org/10.1016/j.jue.2017.05.006.

Vilalta, C.J. (2013). How exactly does place matter in crime analysis? Place, space, and spatial heterogeneity. Journal of Criminal Justice Education, 24(3), 290-315. https://dx.doi.org/10.1080/10511253.2012.715659

Wilcox, P., Quisenberry, N., Cabrera, D.T., \& Shayne, J. (2004). Busy places and broken windows: Toward defining the role of physical structure and process in Community Crime Models. The Sociological Quarterly, 45(2), 185-207. http://dx.doi.org/10.1111/j.15338525.2004.tb00009.x

Wo, J.C. (2019). Mixed land use and neighborhood crime. Social Science Research, 78, 170186. http://dx.doi.org/10.1016/j.ssresearch.2018.12.010

Worboys, M., \& Duckham, M. (2004). GIS: A computing perspective. (2 $2^{\text {nd }}$ ed.). Washington, CRC Press.

Zohreh Mahdiar, \& Melasutra Md Dali. (2016). Adolescent use of urban parks and their social environment consequences. Geografia: Malaysian Journal of Society and Space, 12(11), 123-136.

Zahnow, R. (2018). Mixed land use: Implications for violence and property crime. City \& Community, 17(4), 1119-1142. http://dx.doi.org/10.1111/cico.12337 